\title{
AN EXPERIMENTAL STUDY ON THE RELAXATION OF BOLTS
}

\author{
Muhammad AbID ${ }^{1}$, Muhammad Shahid KhaliL ${ }^{2}$ ANd Hafiz Abdul WaJID ${ }^{3,4}$ \\ ${ }^{1}$ Interdisciplinary Research Centre, COMSATS Institute of Information Technology, \\ Wah Cantt, Pakistan. \\ ${ }^{2}$ Department of Mechanical Engineering, University of Engineering and Technology, \\ Taxila, Pakistan. \\ ${ }^{3}$ Department of Mathematics, COMSATS Institute of Information Technology, \\ Lahore, Pakistan. \\ ${ }^{4}$ Department of Electrical Engineering, Islamic University Medina, \\ Kingdom of Saudi Arabia. \\ drabid@ciitwah.edu.pk
}

(Received 1 January 2015; accepted 14 March 2015; published on line 29 May 2015)

\begin{abstract}
Loss of pre-load with time, commonly known as 'relaxation' is an established phenomena. Behaviour of a bolted joint depends upon the pre-load in the bolts in use, not the pre-load introduced by the mechanic. Loss of pre-load is expected due to many factors such as embedment relaxation, gasket creep, elastic interactions, and vibration loosening or stress relaxation. In a gasketed joint, due to the gasket flexibility, relaxation in almost all bolts is always substantial during preliminary bolt tightening passes, as 80 to $100 \%$ loss is common hence resulting in a dynamic behaviour. It is observed that pre-load in a gasketed joint is controlled to a certain extent only in the final bolt-tightening passes. Experimental study presented in this paper highlights the factors affecting the amount of bolt preload relaxation with time. Important considerations are recommended to reduce bolt relaxation. Both the short and long term relaxations are recorded and a 'best fit' model for relaxation behaviour is derived.
\end{abstract}

ABSTRAK: Kehilangan prabeban berkadaran dengan masa, atau lebih di kenali sebagai 'Relaksasi' adalah fenomena yang sememangnya wujud. Sifat sambungan bolt bergantung kepada prabeban dalam bolt yang digunakan, bukannya prabeban yang dikenakan terhadapnya. Kehilangan prabeban sememangnya dijangkakan; disebabkan oleh beberapa faktor seperti relaksasi pembenaman, rayapan gasket, saling tindak elastik dan kelonggaran getaran atau tegasan relaksasi. Dalam sambungan bergasket, disebabkan oleh fleksibiliti gasket, relaksasi pada hampir semua bolt sering kali mapan sepanjang pengetatan awal laluan, di mana kekurangan sebanyak 80 ke $100 \%$ adalah perkara biasa; seterusnya menghasilkan sifat dinamik. Prabeban pada sambungan gasket dikaji dan dikawal pada peringkat tertentu hanya semasa pengetatan akhir laluan sahaja. Kajian bereksperimen mengetengahkan faktor-faktor penyebab kadar relaksasi prabeban berkadaran dengan masa. Beberapa pertimbangan penting juga dicadangkan untuk mengurangkan relaksasi bolt. Kedua-dua tempoh relaksasi pendek dan panjang telah direkodkan serta model sifat relaksasi yang paling sesuai diperolehi.

KEYWORDS: preload; bolts; relaxation; experimental; joint; gasketed

\section{INTRODUCTION}

From a number of analytical and experimental studies of bolted flanged pipe joints, great importance is attributed to the bolting and assembly of the bolted joints due to 
different bolt behaviour that can be observed [1-17]. In a gasketed joint, the presence of the gasket and rotation of flanges results in joint relaxation and improper preloading of the bolts. In addition to this, gasket crushing and flange yielding limits higher pre-load $[1,15$ 34]. Bolt quality and proper tooling has been proven to be important factors in getting proper pre-load in the joint [1]. In this study, pre-loads of $60 \%, 80 \%$ and more than $100 \%$ were applied to observe both short and long term relaxations. The bolts were also preloaded close to the ultimate tensile strength of the bolt material, to study its relaxation behaviour. This experimental study highlights important factors that affect amount of relaxation in bolts with time and presents important considerations that may be effective in reducing this occurrence. During this study, a bolt calibration unit developed for the measurement of force felt by the bolt was used. Furthermore, both the short and long term relaxations are recorded and a 'best fit' model for relaxation behaviour is derived for different pre-loads. Definitions of relaxation terms are given here for clarity:

Short term relaxation: Most of the relaxation occurs shortly, after the joint has been assembled or at least soon after it has been put into service, due to the number of reasons, such as bolt bending, soft parts (gasket), improper tooling and torquing, bolt quality, nonparallelism of flange joint surfaces, geometric variance and so on.

Long term relaxation: It is generally due to the stress relaxation and vibration loosening. Stress relaxation can be related to the creep, as this is substantial under high temperature applications.

Relaxation measurement: In practice different methods such as application of restarting or breakaway torque, bolt length measurement using ultrasonic extensometers are adopted. However none of these are observed perfect, as it is difficult to measure relaxation.

\section{EXPERIMENTAL SETUP AND PROCEDURE}

A calibration unit consisting of an aluminium cylinder equipped with strain gauges arranged in a Wheatstone full bridge circuit was used for bolt force measurement (Fig. 1a). For better results in recording, an amplifier was also attached with the calibration unit. During the tests, M12 bolts as per ISO-898 grade 8.8 and 10.9 were arranged [35]. Nuts and washers of different thickness and geometry were used in different combinations with these bolts to observe pre-load loss effects. A detailed list of bolts, nuts and washers that were tested is given in Table 1 and the material and strength of the bolts tested are given in Table 2. One bolt from each set was placed in the calibration unit and was applied a given torque using a calibrated electronic torque wrench. Bolts were pre-loaded up to a minimum of $60 \%(48 \mathrm{kN}), 80 \%(65 \mathrm{kN})$ and more than $80 \%(78 \mathrm{kN}$ and $81 \mathrm{kN})$ of their yield strength or proof load. Pre-load was applied in increments of $10 \mathrm{kN}$. After each increment the torque reading from the calibrated electronic torque wrench was recorded. After application of the required pre-load, results for the pre-load drop/loss were recorded in the data logging system and were plotted using a pen plotter. In order to observe the effect of re-tightening on pre-load loss, tests were also carried out with bolts that were retightened after different time intervals. Experimental set up, tools used, nuts, washers and bolts used are shown in Fig. 1b, Fig. 2a and 2b respectively.

\section{DATA PROCESSING}

Data recorded during the bolt relaxation was processed using the Power and Logarithmic Function [1] to find the 'best fit' model. Bolt relaxation for each bolt is calculated for the experimental time as well as for 15 seconds to 10 years. During the first 
5 minutes a drop of only 1 3 percent was observed. For more than 1 day this value varied for different bolts. Relaxation calculated for all the bolts was nearly the same for the first 24 hours whereas for longer periods it was found to be greater for the logarithmic function than for the Power function. Power function was found to be the 'best fit' model for the recorded data. Results for the power function are summarized in Table- 3 for all the bolts tested. Calculations of these correlation factors also include short term relaxation for the first 1 to 2 minutes as the torque wrench is taken off from the nut. However, neglecting the effect of this initial relaxation, a higher value of correlation factor will be obtained and the pre-load loss or relaxation will be very small, but cannot be neglected.

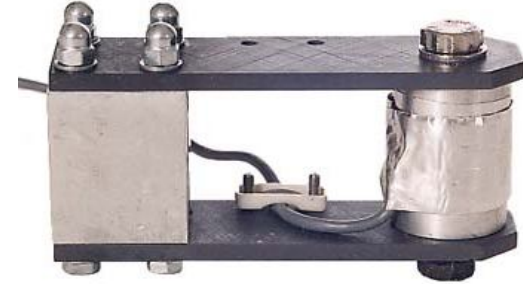

(a)

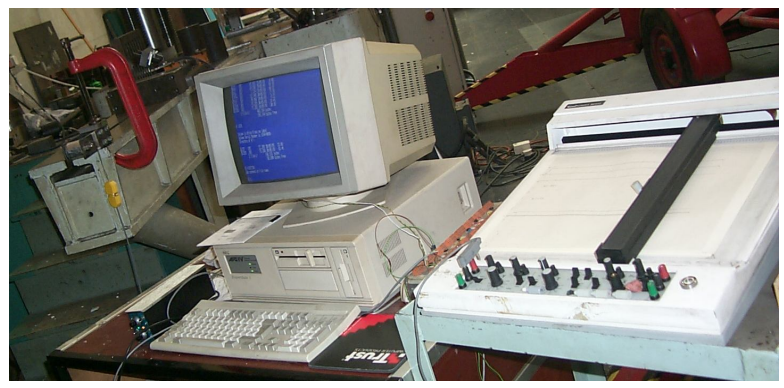

(b)

Fig. 1 (a) Calibration unit, (b) Experimental setup.

Table 1: Details of bolts tested for pre-load applied and pre-load loss

\begin{tabular}{clccccc}
\hline $\begin{array}{c}\text { Bolt } \\
\text { No }\end{array}$ & Bolt Used & $\begin{array}{c}\text { Property } \\
\text { Class }\end{array}$ & $\begin{array}{c}\text { Surface } \\
\text { Treatment }\end{array}$ & $\begin{array}{c}\text { As per code and } \\
\text { marking }\end{array}$ & $\begin{array}{c}\text { Applied } \\
\text { Preload } \\
(\mathbf{k N})\end{array}$ & $\begin{array}{c}\text { Re- } \\
\text { tightened }\end{array}$ \\
\hline 2 & 1st Time & 10.9 & Wax emulsion & SA A4 316L 100M & $66,52,78$ & Yes \\
3 & 1st Time & 10.9 & Wax emulsion & SA A4 316L 100M & $66,52,78$ & No \\
4 & 1st Time & 10.9 & Wax emulsion & SA A4 316L 100M & $66,52,78$ & No \\
5,7 & 1st Time & 10.9 & Dry lubricant & SA A4 316L 100M & 78,81 & No \\
6 & 1st Time & 10.9 & Dry lubricant & SA A4 316L 100M & 81 & Yes \\
6-LN & 1st Time & 10.9 & Dry lubricant & SA A4 316L 100M & 81 & No \\
9 & 1st Time & 8.8 & Bright Zinc & ML8.8 & 81 & No \\
$10-$-LN & 2nd Time & 8.8 & Bright Zinc & ML8.8 & 60 & Yes \\
$10-$-MK & 2nd Time & 8.8 & Bright Zinc & ML8.8 & 60 & Yes \\
& & & \& Molykote & ML8.8 & 60 & No \\
11 & 1st Time & 8.8 & Dry lubricant & ML8.8 & 60 & Yes \\
12 & 2nd Time & 8.8 & Dry lubricant & ML8.8 & 51 & Yes \\
$21(9)$ & 2nd Time & 8.8 & Bright Zinc & Nax & No \\
$22(1)$ & 2nd Time & 10.9 & Wax emulsion & SA A4 316L 100M & 46 & Yes \\
27 (st) & 2nd Time & 8.8 & Dry lubricant & ML8.8 & 43 & Yes \\
$28($ st) & 2nd Time & 8.8 & Dry lubricant & ML8.8 & 41 & \\
\hline
\end{tabular}

Table 2: Properties of the bolts tested

\begin{tabular}{|c|c|c|c|c|c|c|c|}
\hline \multirow[b]{2}{*}{$\begin{array}{l}\text { Bolt } \\
\text { Dia. } \\
\text { (mm) }\end{array}$} & \multirow[b]{2}{*}{$\begin{array}{l}\text { Property } \\
\text { Class }\end{array}$} & \multirow[b]{2}{*}{$\begin{array}{c}\text { Stress } \\
\text { Area } \\
\left(\mathbf{m m}^{2}\right)\end{array}$} & \multirow{2}{*}{$\begin{array}{l}\text { Min. Yield } \\
\text { Strength } \\
\text { (ISO-898) }\end{array}$} & \multirow[b]{2}{*}{$\begin{array}{l}\text { Proof } \\
\text { Load } \\
(k N)\end{array}$} & \multirow[b]{2}{*}{$\begin{array}{c}\text { Min. UT } \\
\text { Load } \\
(\mathbf{k N})\end{array}$} & \multicolumn{2}{|c|}{ Pre-load } \\
\hline & & & & & & $\underset{(\mathrm{kN})}{\text { Recommended }}$ & $\begin{array}{c}\text { Based on } \\
\text { shank area } \\
(\mathbf{k N})\end{array}$ \\
\hline M12 & 10.9 & 84.3 & 900 & 70.0 & 87.7 & 55.0 & 81.43 \\
\hline M12 & 8.8 & 84.3 & 640 & 48.9 & 67.4 & 39.0 & 57.91 \\
\hline
\end{tabular}




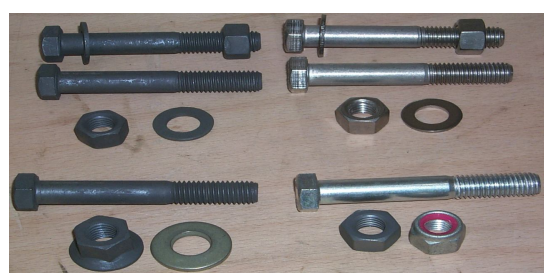

(a)

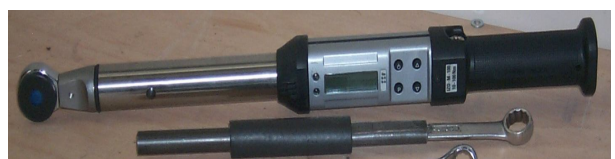

(b)

Fig. 2 (a) Bolts, nuts and washers used during tests, (b) Tools (torque wrenches) used.

Table 3: Preload loss with time for all bolts using Best Fit curve

\begin{tabular}{|c|c|c|c|c|c|c|c|c|c|c|c|}
\hline \multirow[b]{2}{*}{ Bolt No. } & \multirow[b]{2}{*}{$\begin{array}{l}\text { Time } \\
(\mathbf{m i n})\end{array}$} & \multirow[b]{2}{*}{$\begin{array}{c}\text { Correla- } \\
\text { tion } \\
\text { Factor }\end{array}$} & \multirow[b]{2}{*}{$\begin{array}{l}\text { Pre- } \\
\text { load }\end{array}$} & \multirow[b]{2}{*}{$\mathbf{A}$} & \multirow[b]{2}{*}{ B } & \multirow[b]{2}{*}{$\mathbf{x} 1$} & \multirow[b]{2}{*}{$\mathbf{y}$} & \multirow{2}{*}{$\begin{array}{c}\text { y1 } \\
\begin{array}{c}\text { Ini. Tor- } \\
\text { que }\end{array}\end{array}$} & \multicolumn{3}{|c|}{ Relaxation during } \\
\hline & & & & & & & & & $\begin{array}{c}\text { Expe- } \\
\text { rimental } \\
\text { Time }\end{array}$ & $\begin{array}{l}\text { One } \\
\text { day }\end{array}$ & $\begin{array}{l}\text { One } \\
\text { year }\end{array}$ \\
\hline BLT2 & 30.0 & 0.7654 & $>80 \%$ & 54.14 & -0.15 & 0.62 & 58.27 & 65.59 & 11.15 & 23.35 & 66.67 \\
\hline BLT2-R1 & 30.0 & 0.9278 & $>80 \%$ & 60.44 & -0.16 & 0.64 & 64.86 & 65.07 & 0.33 & 14.13 & 63.55 \\
\hline BLT2-R2 & 30.0 & 0.9262 & $>80 \%$ & 61.93 & -0.15 & 0.66 & 65.95 & 66.20 & 0.38 & 13.50 & 62.24 \\
\hline BLT3 & 30.0 & 0.9259 & $>80 \%$ & 49.18 & -0.10 & 0.57 & 52.05 & 52.11 & 0.11 & 9.79 & 47.81 \\
\hline BLT4 & 110.0 & 0.5793 & $>80 \%$ & 67.39 & -0.19 & 0.67 & 72.65 & 74.90 & 3.00 & 18.38 & 70.58 \\
\hline BLT6 & 70.0 & 0.7371 & $>80 \%$ & 66.37 & -0.70 & 0.78 & 78.63 & 80.80 & 2.68 & 45.26 & 98.68 \\
\hline BLT6-R1 & 30.0 & 0.8356 & $>80 \%$ & 70.91 & -0.56 & 0.81 & 79.99 & 81.02 & 1.26 & 37.13 & 96.78 \\
\hline BLT6-R2 & 15.0 & 0.8734 & $>80 \%$ & 73.84 & -0.47 & 0.83 & 80.71 & 81.48 & 0.94 & 31.75 & 94.35 \\
\hline BLT6-LN & 120.0 & 0.6582 & $>80 \%$ & 75.56 & -0.04 & 0.22 & 80.16 & 80.79 & 0.77 & 7.21 & 25.91 \\
\hline BLT7 & 794.0 & 0.8190 & $>80 \%$ & 51.66 & -0.09 & 0.24 & 58.41 & 59.16 & 1.27 & 14.26 & 47.34 \\
\hline BLT9 & 65.0 & 0.8812 & $>80 \%$ & 74.16 & -0.10 & 0.50 & 79.52 & 80.79 & 1.57 & 11.86 & 49.24 \\
\hline BLT10-LN-R1 & 22.0 & 0.9374 & $>80 \%$ & 60.57 & -0.71 & 0.99 & 61.22 & 61.49 & 0.44 & 39.39 & 98.49 \\
\hline BLT10-MK & 20.0 & 0.7771 & $>80 \%$ & 48.83 & -0.08 & 0.06 & 60.94 & 61.58 & 1.04 & 21.10 & 50.63 \\
\hline BLT10-MK-R1 & 60.0 & 0.8933 & $>80 \%$ & 55.83 & -0.04 & 0.07 & 61.44 & 61.70 & 0.42 & 9.74 & 26.92 \\
\hline BLT12 & 72.0 & 0.6205 & $>80 \%$ & 54.30 & -0.30 & 0.80 & 58.14 & 59.24 & 1.87 & 23.05 & 84.28 \\
\hline BLT12-R1 & 63.0 & 0.8679 & $>80 \%$ & 57.52 & -0.22 & 0.85 & 59.66 & 59.85 & 0.32 & 15.91 & 73.46 \\
\hline BLT21 & 44.0 & 0.7520 & $80 \%$ & 48.37 & -0.02 & 0.20 & 49.85 & 50.68 & 1.65 & 4.90 & 14.59 \\
\hline BLT21-R1 & 40.0 & 0.9266 & $>80 \%$ & 48.13 & -0.04 & 0.25 & 50.76 & 50.87 & 0.22 & 6.18 & 24.43 \\
\hline BLT22 & 25.0 & 0.7622 & $60 \%$ & 44.71 & -0.17 & 0.28 & 55.82 & 42.26 & -32.1 & -1.36 & 62.08 \\
\hline BLT27 & 20.0 & 0.7308 & $80 \%$ & 34.45 & -0.18 & 0.31 & 42.46 & 42.90 & 1.01 & 23.37 & 71.59 \\
\hline BLT27-R1 & 10.0 & 0.7162 & $80 \%$ & 36.41 & -0.17 & 0.32 & 44.30 & 44.40 & 0.22 & 21.81 & 70.23 \\
\hline BLT27-R2 & 10.0 & 0.5406 & $80 \%$ & 40.45 & -0.10 & 0.33 & 45.27 & 45.40 & 0.28 & 13.41 & 50.85 \\
\hline BLT28T & 40.0 & 0.7556 & $80 \%$ & 38.68 & -0.10 & 0.70 & 40.04 & 40.30 & 0.64 & 8.78 & 45.54 \\
\hline BLT28T-R1 & 44.0 & 0.7898 & $80 \%$ & 39.57 & -0.03 & 0.76 & 39.95 & 40.00 & 0.12 & 2.96 & 19.16 \\
\hline BLT28T-R2 & 36.0 & 0.8076 & $80 \%$ & 39.59 & -0.03 & 0.72 & 39.95 & 40.02 & 0.16 & 2.56 & 16.18 \\
\hline BLT28R & 35.0 & 0.8349 & $60 \%$ & 29.34 & -0.11 & 0.78 & 30.15 & 30.25 & 0.32 & 9.00 & 49.50 \\
\hline BLT28R-R1 & 38.0 & 0.7941 & $60 \%$ & 29.94 & -0.02 & 0.83 & 30.04 & 31.00 & 3.09 & 4.54 & 13.72 \\
\hline
\end{tabular}

\section{RESULTS AND DISCUSSION}

Results for different bolts 2-7, 10 and 21 which are plotted in Fig. 3 to Fig. 8, and summarized in Table 3 are discussed below. 


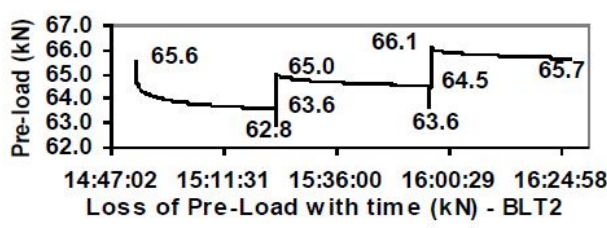

(a)

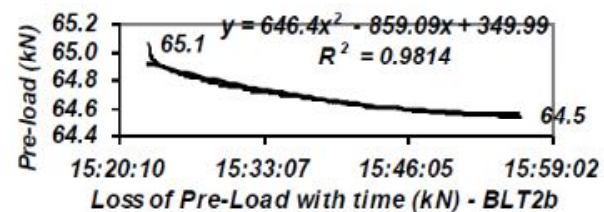

(c)

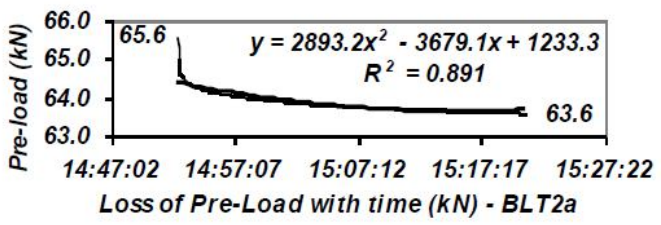

(b)

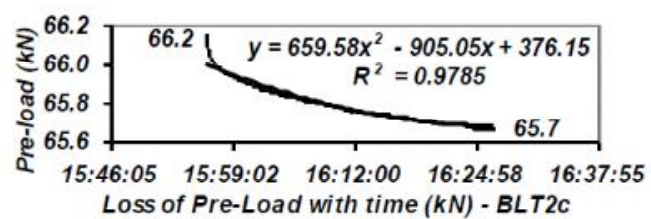

(d)

Fig. 3: Loss of Pre-load with Time for Bolt-2. (a) Overall tightening, (b) First tight, (c)

First Re-tight, (d) Second Re-tight.

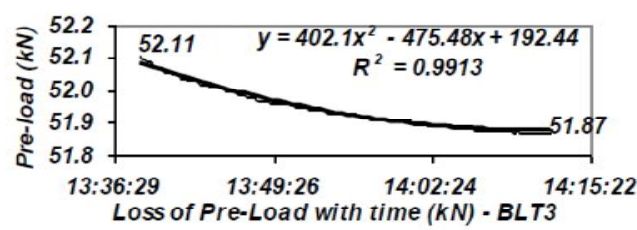

(a)

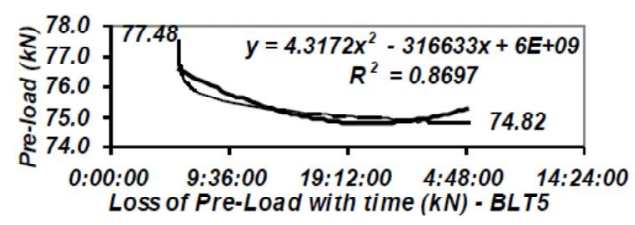

(c)

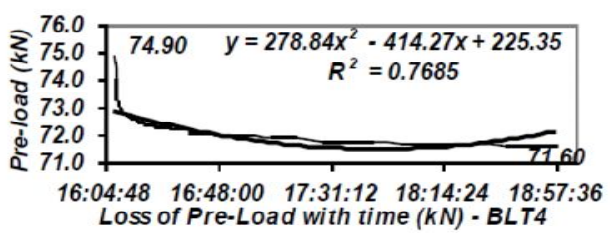

(b)

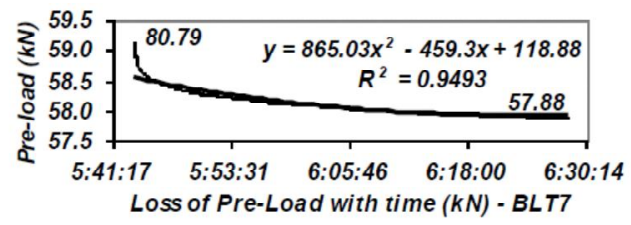

(d)

Fig. 4 Loss of Pre-load with Time. (a) Bolt-3, (b) Bolt-4, (c) Bolt-5, (d) Bolt-7.

\subsection{Pre-load Above 80\% of the Minimum Yield Strength of Bolt Material}

During these tests, the bolts were torqued above the recommended value of $80 \%$ of bolt yield [1-7]. Pre-load applied is given in Table 2. The purpose was to see its effect on the loss of pre-load. For all the bolts, during the first 1 to 2 minutes a rapid loss of pre-load was observed. This drop was different for different bolts. A variation in pre-load loss of 0.5 to $2 \mathrm{kN}$ was noted which was about 1 to 3 percent of the initially applied torque. This is always expected from the bolt as the torque wrench or hydraulic tensioner is removed from the bolt. After 3 to 4 minutes, steady and continuous pre-load drop behaviour was recorded for all the bolts. All the bolts (BLT1 BLT12) were tested for the first time and results were recorded for different time intervals ranging from 10 minutes to 24 hours. Results were used to obtain the best fit model via curve fitting. Three models, namely the logarithmic, power and exponential models were tried. All were found to be very close to each other. The correlation factor for all the bolts was found ranging from 0.6205 to 0.9252. There were no visible difference in the results of bolts noted for different surface treatments and grades. 


\subsection{Pre-load of $80 \%$ of the Minimum Yield Strength of Bolt Material}

The bolts were pre-loaded to the recommended value of $80 \%$ of bolt yield [1-7]. Preload applied is given in Table 2. A very small drop of pre-load was observed for all the bolts during the first 1 to 2 minutes, which became very steady and nearly negligible. All the bolts (BLT12 BLT28) were tested for the second time and results were recorded for different time intervals ranging from 10 minutes to 24 hours. Results were used to obtain the best fit model via curve fitting. Three models, namely the logarithmic, power and exponential models were tried. All were found to be very close to each other. the correlation factor for all the bolts was found ranging from 0.7308 to 0.9 . There were no visible difference in the results of bolts noted for different surface treatments and grades.

\subsection{Effect of Lock Nuts and Lubricants}

This study was carried out to see the effect of lock-nut and lubricant on the loss of pre-load. Bolt number 6 and 10 were tried with lock-nut for a pre-load of above $80 \%$. It was noted during the test that the proper strength of the Nyloc could not be utilised due to the bolt length. Only two to three threads were utilised. However, the results recorded are presented in graphs for BLT6-LN and BLT-10N. A correlation factor of 0.6582 to 0.6652 was calculated. Bolt BLT10 was used with Molykote lubricant for the pre-load of about $80 \%$ and a comparatively good correlation factor of 0.8359 was observed.

\subsection{Effect of Re-tightening}

Bolt relaxation during the first few seconds or minutes was observed to be rapid as the torque wrench is taken off the nut. However, rapidly it becomes very slow. This study was conducted during the actual situations for the first loading during proof testing and even after first tightening pre-load is reduced. The bolts were re-tightened after different intervals of time to see its effect on bolt relaxation. It was noted that re-tightening has a pronounced effect on the pre-load loss control as also highlighted by Bickford and Abid $[1,13]$. Some of the bolts were re-tightened twice after the first tightening. The correlation factor was noted to be higher and an initial pre-load drop was observed.

For some of the bolts, results that were recorded were not found to be good. During re-tightening a smaller correlation factor was observed, e.g. for bolt BLT27 and BLT28R. This was due to a disturbance to the data logging system due to the use of some of the lab machines for routine maintenance. However, from the results plotted on a flat bed plotter and from the recorded results nearly the same behaviour was observed.

\subsection{Effect of Tightening Speed and Number of Passes}

During the present experimental study, the effect of bolt tightening speed was also found to be important in controlling pre-load loss. It was observed that the bolts that were tightened fast, may not have time to settle in during the tightening process. These may relax more after the tightening procedure. However, during the present study this effect was not recorded and is planned for future studies. In order to compensate for such factors, re-tightening of bolts is strongly recommended [1]. Similarly, tightening of bolts in a series of passes to assemble the joint uniformly, rather than applying full torque on the first pass allows time for relaxation. For both of these reasons, progressive tightening is concluded a virtual necessity on large gasketed joints.

\subsection{Proper Tooling and Fastener Dimensions}

At the start of experiments, no consideration was given to the tooling required for the bolts. However, it was found that some bolts are of metric dimensions and some were not. Even for the same metric dimensions, nut and bolt heads of different dimensions were 
observed e.g. for M12 bolt some were observed of 18-mm and some of 19-mm. Different tools available in the lab i.e. conventional torque wrenches, open ring spanners, long handle spanner, electronic calibrated torque wrench were used to highlight the importance of proper tooling to get a required higher pre-load (Fig. 2b). Using conventional ring or open spanners it was found to be very difficult to tighten the bolts and using these tools the bolt head and nut hexagonal geometry were damaged. Sometimes experiments were stopped because of the unavailability of the proper spanner due to the varying dimension of the bolt head or nut. It was also found that the bolts with the same marking have large variation in their quality, geometry, surface finish and other parameters. The bolts used in this study hadvery good quality with proper surface treatment. However torque variation is still observed in the recorded data. It is also observed that the quality of bolts can't be guaranteed from unknown manufacturers or suppliers. Hence only well known bolt manufacturers should be selected to ensure bolted joint performance for safe joint strength and sealing.

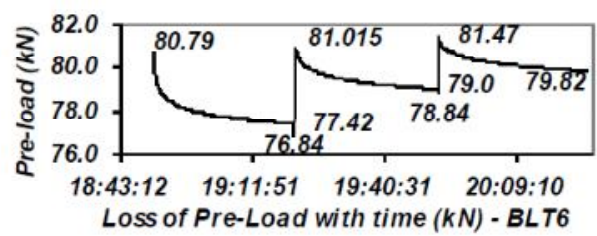

(a)

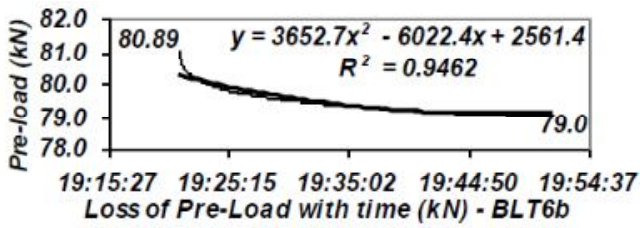

(c)

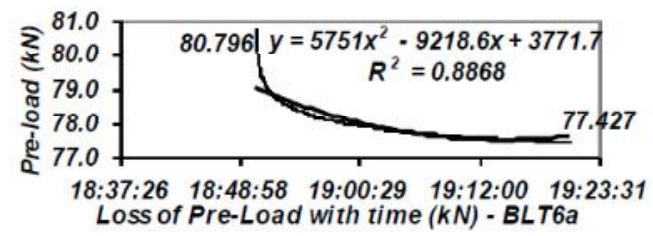

(b)

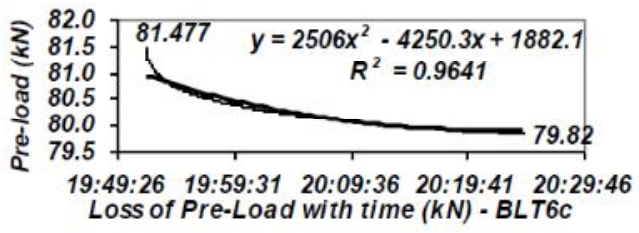

(d)

Fig. 5 Loss of Pre-load with Time for Bolt 6. (a) Overall tightening, (b) First tight, (c) First Re-tight, (d) Second Re-tight.

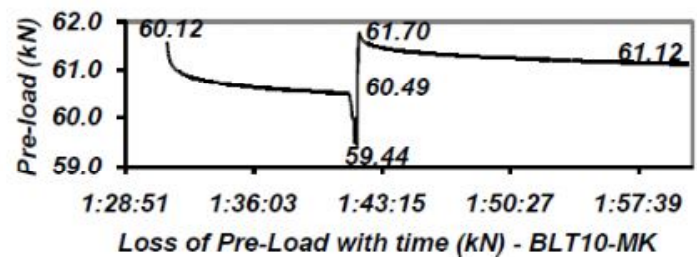

(a)

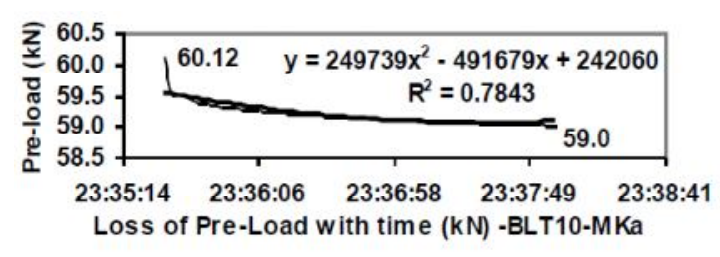

(b)

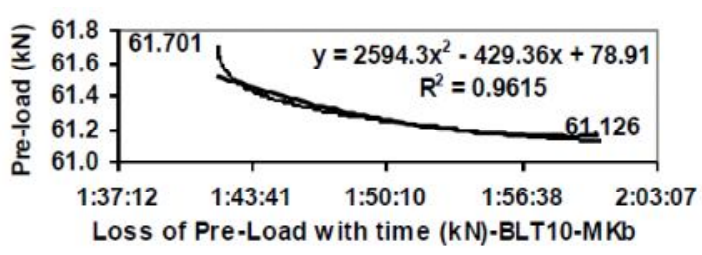

(c)

Fig. 6 Loss of Pre-load with Time for Bolt 10 with Molykot lubricant. (a) Overall tightening, (b) First tight, (c) First Re-tight. 


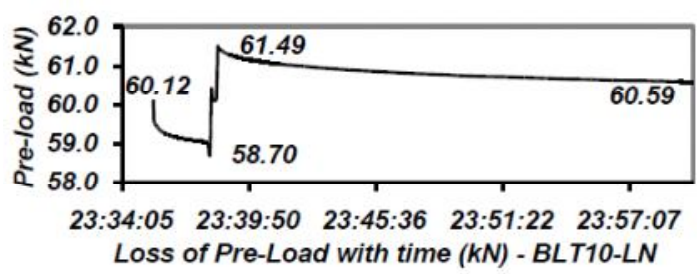

(a)

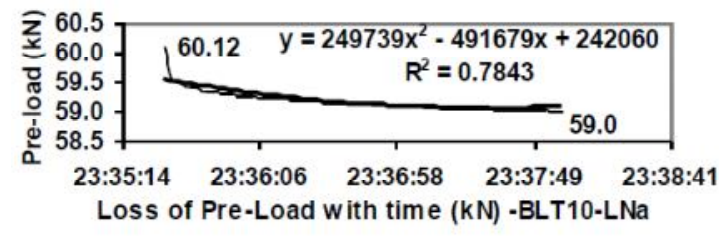

(b)

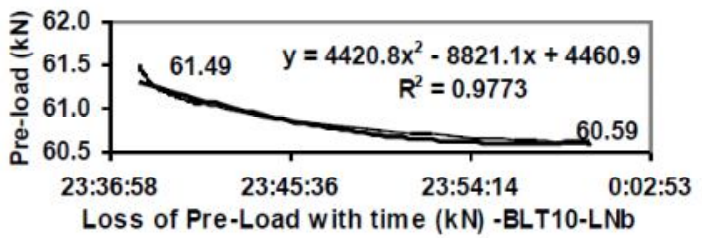

(c)

Fig. 7: Loss of Pre-load with Time for Bolt 10 with Locknut. (a) Overall tightening, (b) First tight, (c) First Re-tight.

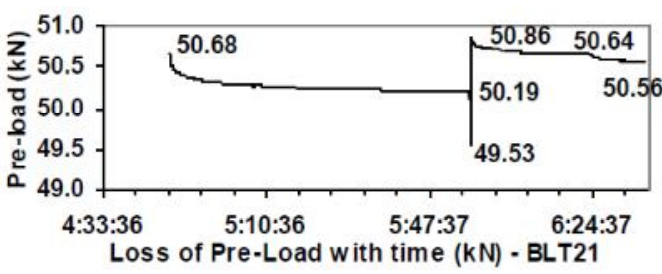

(a)

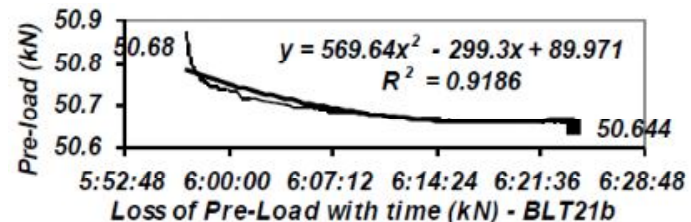

(c)

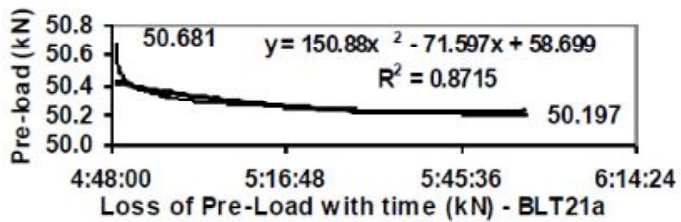

(b)

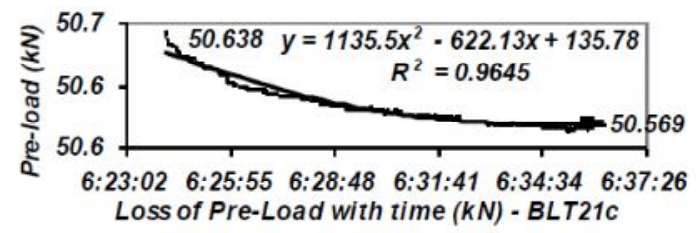

(d)

Fig. 8 Loss of Pre-load with Time for Bolt 21. (a) Overall tightening, (b) First tight, (c)

First Re-tight, (d) Second Re-tight.

\section{CONCLUSIONS AND RECOMMENDATIONS}

In light of the results and observations, the following conclusions and recommendations are made;

- Use of new, good quality and high strength bolts with original surface treatment, i.e. dry lubricant, proper bolt tightening speed by properly trained fitters, and with initial higher preload to compensate for the pre-load loss is recommended.

- Use of good quality locknuts and washers and proper tooling, preferably ring spanners instead of open spanners, are recommended.

- Re-tightening of the bolts after a few minutes to several hours and even after proof testing is very important.

- To avoid embedment relaxation, it is recommended that bolts are used after undergoingseveral passes of loosening and tightening. Embedment relaxation may be worse for new bolts. 
More than one bolt tightening pass with proper bolt tightening sequence is recommended to achieve uniform preload bolts used in a joint.

\section{REFERENCES}

[1] Abid M. (2000) Experimental and analytical studies of conventional (gasketed) and unconventional (non gasketed) flanged pipe joints (with special emphasis on the engineering of 'joint strength' and 'sealing'. PhD Thesis, University of Strathclyde, Glasgow, UK.

[2] Webjörn J. (2000) The loss of bolt pre-load with time. Document no. J0001.01 doc F46.

[3] Webjörn J. (1985) New look at bolted joint design. Machine Design, pp. 81-84.

[4] Webjörn J. (1985) The bolted joint - A series of problems. Linköping Studies in Science and Technology, Dissertation No. 130, Appendix A.

[5] Webjörn J. (1986) The Development of Compact Flanges". International Symposium on Fluid Sealing (CETIM), Nantes, France, pp. 45-48.

[6] Webjörn J. (1990) Discussion - An alternative bolted joint for pipe-work. Proc. Instn. Mechanical Engineers, 204:139-140.

[7] Webjörn J. ("Discussion-An alternative bolted joint for pipe-work". Proc. Instn. Mechanical Engineers, 205:59-62.

[8] Almen JO. (1943) Bolt failure as affected by tightening. Machine Design, pp. 133-134.

[9] Almen JO. (1994) Tightening is vital factor in bolt endurance. Machine Design, pp. 158-162.

[10] Chesson EJR, Munse WH. (1964) Studies of the behaviour of high strength bolts and bolted joints. University of Illinois College of Engineering, Engineering Experiment Station Bulletin 469.

[11] Roehrich LR. (1967) Torquing stresses in lubricated bolts. Machine Design, pp. 171-175.

[12] Bickford JH. (1981) An introduction to the design and behaviour of bolted joints, CRC Press.

[13] Bickford JH. (1983) That initial pre-load: What happens to it. Mechanical Engineering, pp. 5761.

[14] Haviland GS. (1983) Designing with threaded fasteners. Mechanical Engineering, pp. 17-31.

[15] Abid M, Nash DH. (2005) Structural strength: Gasketed versus non-gasketed flange joint under bolt up and operating condition. Int. J. Solids and Structures, 217:1-14.

[16] Abid M. (2006) Stress variation in flange of a gasketed flanged pipe joint during bolt up and operating conditions". Int. J. Sci. Tech. - Scientia Iranica, 13(3):303-309.

[17] Abid M, Nash DH, Webjörn J. (2000) The stamina of non-gasketed flanges. Fatigue 2000, Cambridge, pp. 575-584.

[18] Abid M, Nash DH. (2006) Relaxation behaviour of a gasketed and non-gasketed bolted flanged pipe joint - A comparative study. WSEAS Transactions on Applied and Theoretical Mechanics, 1(2):239-246.

[19] Abid M, Hussain S. (2008) Gasketed flange joint's relaxation behaviour during assembly using spiral wound gasket. J. Process Mech. Eng., Proceedings of the IMechE, Part E, 222(2):123-134.

[20] Abid M, Nash DH. (2006) Bolt bending behaviour in a bolted flanged pipe joint: A comparative study".ASME Pressure Vessel and Piping Conference, Hyatt Regency Vancouver, Vancouver, British Columbia, Canada, July 23-27, pp. 1-9.

[21] Abid M, Nash DH. (2006) Joint relaxation behaviour of gasketed bolted flanged pipe joint during joint assembly. $2^{\text {nd }}$ WSEAS International Conference on Applied and Theoretical Mechanics (MECHANICS'06) TTVenice, Italy, November 20-22, pp. 319-325.

[22] Abid M, Hussain S. (2007) Bolted joint's relaxation behavior: A FEA study. Failure of Engineering Materials and Structures. FEMS, UET Taxila, Pakistan, 22-23 October, pp. 143-153.

[23] Abid M, Hussain S. (2008) Gasketed joint's relaxation behavior during assembly using different gaskets: A comparative study. International conference on advanced design and manufacturing (ICADAM2008), 14-16 January, Haiksou China. pp. 1-10. 
[24] Abid M. (2008) Effect of bolt scatter on different sizes of gasketed bolted flange joints: A comparative FE study. $13^{\text {th }}$ International conference on Applied Mechanics and Mechanical Engineering (AMME-13), May 27-29, Cairo, Egypt, pp. 1-14.

[25] Kamran AK, Abid M, Chattha JA. (2009) Gasketed bolted flange joint's relaxation behavior under different bolt up strategy. Proc. IMechE, Part E: J. Process Mechanical Engineering, 223(4):259-263.

[26] ASME (2010) Guidelines for pressure boundary bolted flange joint assembly. ASME PCC1-2010. USA.

[27] Abid M, Hussain S. (2010) Gasketed flange joint's relaxation behaviour during assembly. SADHANA Indian Academy of Sciences Proceedings in Engineering Sciences, 35(1):3143.

[28] Abid M. (2010) Behaviour of the gasketed flange joints of different sizes - A parametric FEA study. The Technology World Journal. II(1):101-106.

[29] Abid M, Shah AR. (2011) Performance of a gasketed bolted flanged pipe joint under boltup, internal pressure and dynamic (harmonic and transient) axial loads. NED University Journal of Research, 2:62-69.

[30] Abid M, Maqsood S, Wajid HA. (2012) Comparative modal analysis of gasketed and nongasketed bolted flanged pipe joints: FEA Approach. Adv. Mech. Eng. pp. 1-8. doi:10.1155/2012/413583. 2012.

[31] Abid M, Khan YM. (2013) The effect of bolt tightening methods and sequence on the performance of gasketed bolted flange joint assembly. Structural Engineering and Mechanics, 46(6):843-852.

[32] Abid M, Khan KA, Chattha JA. (2013) Performance testing of a gasketed bolted flange pipe joint under combined pressure and thermal loading. Experimental Techniques, pp. 1-3.

[33] Abid M. (2010) Comparative performance study of gasketed and non-gasketed flange joints under combined internal pressure, axial and bending loading - An experimental study. IIUM Engineering Journal, 11(2):179-200.

[34] Abid M, Al-Grafi MW, Wajid HA. (2013) Effect of bolt behaviour on the performance of a bolted joint". World Applied Sciences Journal, 26(1):89-96.

[35] BS 3692 (1967) Specifications for ISO metric precision hexagonal bolts, screws and nut.

\section{NOMENCLATURE}

$x \quad$ Independent variable

$y \quad$ Dependent variable

$m \quad$ Slope of line

$a, b \quad$ Constants

LN With Lock-nut (Nyloc)

MK With lubricant Molykote 321R 